\title{
SOME PROPERTIES OF FRIED EGGPLANT SLICES AFFECTING BY PRE- DRYING IN MICROWAVE OVEN
}

\author{
Samak, A. A. ${ }^{(1)}$, M. H. Keshek ${ }^{(1)}$, and M. N. Omar ${ }^{(1)}$ \\ ABSTRACT
}

Fried eggplant one of the most important foods favored by man but during fry the eggplant change in color, oil uptake and texture occurred, so that the main aim of this paper is to study the effect of microwave predrying on fried eggplant slices characteristics. To achieve this aim, eggplant slices with thicknesses 1,2, and $3 \mathrm{~cm}$ were dried in microwave using 720, 540, and 360 Watt of microwave powers for 2,4,6, and 8 minutes before frying it in oil for 3,5, and 7 minutes. The study explained that $0.01 \%$ highly significant effect of microwave powers on frying yield, $0.05 \%$ high significant of drying time and non-significant effect of slices thicknesses and frying time. The firmness of eggplant slices was $0.01 \%$ highly significant affecting by drying time, but it was non-significant affecting by microwave powers; eggplant slices thicknesses and frying time. The frying time result in $0.01 \%$ highly significant effect on $\Delta E$, but the microwave powers and eggplant slices thicknesses resulted $0.05 \%$ significant effect where drying time give non-significant effect. Finally, drying the eggplant slice with $1 \mathrm{~cm}$ thickness using 540 Watt of microwave power for 8 minutes before frying it in oil for 7 minutes resulted a good properties of fried eggplant.

Key words: Eggplant, Drying, Frying, Firmness, Color.

\section{INTRODUCTION}

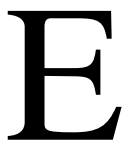

ggplant is a high source of minerals and vitamins, especially in phosphorus and potassium. It contains a variety of phytochemicals such as phenolics and flavonoids Akanitapichat et al., (2010). It is ranked amongst the higher ten vegetables in terms of antioxidant amount because the phenolic constituents Cao et al., (1996). FAOSTAT, (2015) presented that global production of eggplants was 49.4 million tones. India (27\% of world total), Iran, Egypt and Turkey were also central producers that, combined with other Asian countries,

(1) Lecturer, Agricultural Engineering Department, Menoufia University 
comprise $94 \%$ of world production. Egypt production 1.2 million of tones. Man has enjoyed fried foods for thousands of years, the main reason being that these foods have unique and delicious sensory characteristics Stier, (2000). Deep-fat frying is a dry cooking operation, which depend essentially on the inundation the slices of food in hot vegetable oil Moyano et al., (2002). It is a vastly used method for preparing tasty foods that have soft and moist interior together with the crispy crust Garcia et al., (2002). During frying, concurrent heat and mass transfer occur. Upon addition of the food to the hot oil, the surface temperature of the food rises and the moisture at the surface at once starts boiling. Due to the evaporation, surface drying is seen. The evaporation also leads to shrinkage and crust formation Mellema, (2003) and Berk et al., (2009). Heat transferred from the oil to the food causes migration the moisture from the core of food to steam, which make a pressure penchant as the surface dries out by the help of capillaries and channels in the cellular structure this pressure gradient within the product gently 'pumps' the moisture from the core of the food to the crust, which will remove during frying. At the same time, oil adheres to product's surface at the damaged areas and enters the space left by the moisture vapor Debnath et al., (2003). The fact that the vapor leaves spaces for the oil to enter, is the reason why the moisture content of the food largely determines oil uptake Southern et al, (2000). Especially at high moisture content, vapor protects the food from oil absorption by creating an overpressure inside the pores. This barrier property of vapor maybe continues until a few seconds after removal of the food from the oil. After taking the food out of the fryer the temperature drops and the vapor in the pores condensates Mellema. This condensation mechanism creates vacuum effect, which causes the adhering oil being pulled into the product Debnath et al., (2003). Moisture plays a role during frying process, it takes away thermal energy from the hot frying oil surrounding the frying food. This removal of energy by conversion of liquid water to steam prevents burning caused by excessive dehydration at the surface of the product. Therefore, despite the fact that the oil may be at $170 \mathrm{o}$ C, the frying food is only about 100 ${ }^{\circ} \mathrm{C}$, which represents phase change temperature. Another function of water is to cook the interior of frying food Blumenthal, (1991). 
Eissa et al., (2013) notified that oil absorption in deep-fat frying is a ganglion process that including various factors concerned to the food, such as composition and surface characteristics, and factors concerned to the frying process such as frying medium, temperature, time, pre-frying handling and pretreatments. The results indicated that fried eggplants rings at $180{ }^{\circ} \mathrm{C}$ for 4 minutes were the most preferred in all studied characteristics (sensory properties, color characteristics, moisture content and oil content) than other time and temperature fried samples. Fats and oils play important functional and sensory roles in food products. They are responsible for carrying, enhancing, and releasing the flavor of other ingredients, as well as for interacting with other ingredients to develop the texture and mouth-feel characteristics of fried foods Giese, (1996). This absorbed fat exerts a tenderizing effect on the crust, as well as a wetting effect on the food, and thus contributes for the popularity of deep fried foods, namely, their flavor, crispness and pleasant eating characteristics Stevens, et al, (1984). Fried foods at the optimum temperature and times have golden brown color, are properly cooked, and crispy, and have optimal oil absorption. fried foods at lower temperature or shorter frying time than the optimum have white or slightly brown color at the edge, and have ungelatinized or partially cooked starch at the center Choee and Min, (2007). The consumer generally uses the color of a product in order to determine the end of the frying process. The final color of the fried product depends on the absorption of oil and the chemical reactions of browning of reducing sugars and protein sources Baixauli et al., (2002). Frying temperatures can range from $130{ }^{\circ} \mathrm{C}$ to $190{ }^{\circ} \mathrm{C}$, but the most common temperatures are $170-190{ }^{\circ} \mathrm{C}$. The high temperature of the frying fat typically leads to the appreciated surface color and mechanical characteristics of fried foods, and besides, heating of reducing sugars affects a complex group of reactions, termed caramelization, leading to browning development which defines the color of the final product Arabhosseini et al, (2009). The main objectives of this work are firstly, to reduce eggplant absorption of frying oil by pre-drying it by using microwave oven. Secondly, to determine the appropriate thickness of the eggplant slices for pre-drying and frying based on some quality properties such as color and texture. Finally, to determine the most suitable 
microwave oven power for eggplant slices drying and the appropriate drying time to reduce its consumption of frying oil based on frying yield.

\section{MATERIALS AND METHODS}

Eggplant (Solanums melongena) samples were obtained from local market. Each eggplant with approximately 92\% moisture content was rinsed with water, peeled and cut to slices with $5 \mathrm{~cm}$ diameter and different thickness $(1,2$, and $3 \mathrm{~cm})$. The eggplant slices were dried using microwave oven with different levels of powers (720, 540, and 360 Watt) for different times $(2,4,6$, and 8 minutes). Sunflower oil was used to fry the eggplant slices after drying using the microwave oven (KOR-9G2B). The eggplant slices without drying as a control treatment and the dried eggplant slices immersion in fryer filled with $1.5 \mathrm{~L}$ of sunflower oil at temperature $180 \pm 2{ }^{\circ} \mathrm{C}$ to fry it with different times of 3,5 , and 7 minutes.

\subsection{Frying Yield}

Frying yield percentage was obtained by considering the weights of the fried eggplant slices and the fresh eggplant slices after coating. Frying yield percentage was calculated using the equation (1), which reported by Akdeniz, (2004):

$$
\text { Frying Yield Percentage }=\frac{C W}{C} * 100
$$

Where: $\mathrm{CW}$ is fried weight of eggplant slices by $(\mathrm{g})$, and $\mathrm{C}$ is weight of non- fried eggplant slices by $(\mathrm{g})$.

\subsection{Firmness Determination}

Digital instrument Fruit firmness Tester (FHT-1122) was used to measure the firmness of the eggplant samples. Its armature diameter $7 \mathrm{~mm}$ was pressed on the eggplant slices by deeply $0.5 \mathrm{~cm}$.

\subsection{Colour Determination and Evaluation}

Surface colour of the eggplant samples was measured using a WR-10 Colorimeter on its surface at each predetermined level of moisture content during the drying process as shown in figure 2 . The $\mathrm{L}, \mathrm{a}$ and $\mathrm{b}$ indexes were used to evaluate the color change of the eggplant during the drying process. The $\mathrm{L}$ (lightness: $\mathrm{L}=0$ for black, $\mathrm{L}=100$ for white), $\mathrm{a}<0$ for green, $a>0$ for red) and $b$ (yellowness-blueness: $b<0$ for blue, $b>0$ for yellow) 
according to the CIELAB (Commission Internationale de l'éclairage, $\mathrm{L}$, $\mathrm{a}, \mathrm{b})$ colorimetric system. The average color parameters of fresh eggplant were used as a reference $(L=73.23, a=-0.212, b=19.73)$. The changing in the surface color of the sample, which was referred to as the total color difference. Then, the total color difference $(\Delta \mathrm{E})$ and browning index $(\mathrm{Bi})$ were determined using the following equations (2), (3) and (4) according to Korteiet et al, (2015):

$$
\begin{aligned}
& \Delta \mathrm{E}=\sqrt{(\Delta \mathrm{L})^{2}+(\Delta \mathrm{a})^{2}+(\Delta \mathrm{b})^{2}} \\
& \mathbf{B i}=\frac{[100(\mathrm{x}-0.31)]}{0.17} \\
& \mathbf{x}=\frac{(\mathrm{a}+1.75 \mathrm{~L})}{(5.645 \mathrm{~L}+\mathrm{a}-3.012 \mathrm{~b})}
\end{aligned}
$$

Where, the Browning index (Bi) represents the purity of brown color and it considered as an important parameter associated with browning.

\section{RESULTS AND DISCUSSION}

The initial moisture content of the eggplant slices was around $92 \%$ wet basis (11.5 gw/g dry matter) .Eggplant slices were dried using the microwave at selected power levels and at different levels of drying times before the frying process. The table (1) shows the moisture contents of the eggplant slices after the drying process.

Table (1): Eggplant slices moisture content (\% w.b) after drying using microwave with different powers levels and different drying times.

\begin{tabular}{|c|c|c|c|c|}
\hline \multirow{2}{*}{$\begin{array}{c}\text { Microwave power } \\
\text { (Watt) }\end{array}$} & $\begin{array}{c}\text { Drying time } \\
\text { (min.) }\end{array}$ & \multicolumn{3}{|c|}{ Slices thickness (cm) } \\
\cline { 2 - 5 } & 2 & $\mathbf{1}$ & $\mathbf{2}$ & $\mathbf{3}$ \\
\hline \multirow{4}{*}{720} & 4 & 22.73 & 40.25 & 56.24 \\
\cline { 2 - 5 } & 6 & 5.26 & 28.95 & 38.63 \\
\cline { 2 - 5 } & 8 & 2.31 & 11.92 & 29.08 \\
\hline \multirow{4}{*}{540} & 2 & 88.70 & 89.22 & 90.23 \\
\cline { 2 - 5 } & 4 & 80.99 & 84.52 & 87.99 \\
\cline { 2 - 5 } & 6 & 56.76 & 72.14 & 80.76 \\
\cline { 2 - 5 } & 8 & 35.62 & 43.58 & 45.54 \\
\hline \multirow{4}{*}{320} & 2 & 91.12 & 91.31 & 91.37 \\
\cline { 2 - 5 } & 4 & 87.76 & 88.14 & 89.45 \\
\cline { 2 - 5 } & 6 & 86.69 & 86.78 & 88.92 \\
\cline { 2 - 5 } & 8 & 75.47 & 76.98 & 81.38 \\
\hline
\end{tabular}


After eggplant drying process, the samples were fried in vegetables oil to study the effect of drying process on fried slices. The found results were presented in the following items:

\subsection{Frying Yield}

The decrease in frying yield means the moisture loss rate is higher than that of oil uptake Parinyarisi, et al., (1991). Figures 1 (a, b, and c) present the frying yield of eggplant slices as a result of different treatments and its illustrated that the frying yield of fresh samples were higher in comparison with other experimental treatments. Parinyarisi, et al., (1991), found that the same results. The higher frying yield was occurred in samples with $3 \mathrm{~cm}$ thickness, 7 minutes frying time, 360 Watt of microwave power, and 2 minutes drying time. While, the lower frying yield was obtained in samples with $1 \mathrm{~cm}$ slice thickness, 3 minutes of frying time, 720 Watt of microwave power, and 8 minutes drying time. Statistically, highly significant deference (at $0.01 \%$ ) were found between the experimental treatments for the effect of using microwave powers. While, significantly deference (at $0.05 \%$ ) were observed for the drying times. However, there were no significantly deference were found for both the eggplant slices thicknesses and the frying times on frying yield.

\subsection{Firmness of Eggplant slices}

One of the most appreciated characteristics in fried products is an external firmness without being very hard Salvador, et al., (2002). The means statistically significantly data analysis is a good indicator of firmness and figures 2 ( $a, b$, and $c)$ illustrated that, the firmness of eggplant slices was $0.01 \%$ highly significant affecting by drying time, but it was nonsignificant affecting by the microwave powers, eggplant slices thicknesses and frying time. The lowest value of firmness is 0.00918 $\mathrm{Ncm}^{-2}$ occurred when fry eggplant slice with $3 \mathrm{~cm}$ thickness in oil for 3 minutes after drying it using the microwave with power 720 Watt for 2 minutes. The higher value of firmness was $0.2633 \mathrm{Ncm}^{-2}$ occurred when fry eggplant slice with $2 \mathrm{~cm}$ thickness in oil for 7 minutes after drying it in the microwave with power of $720 \mathrm{Watt}$ for 6 minutes.

\subsection{The total difference of the color parameters $(\Delta E)$}

The total difference of the color parameters $\Delta \mathrm{E}$ for fresh eggplant slices and eggplant slices after drying by microwave with powers $(720,540$, and 
360 Watt) for a period of times (1, 4, 6, and 8 minutes) and fry it in oil for times $(3,5$, and 7 minutes) are presented in figures 3 (a, b, and $c)$.

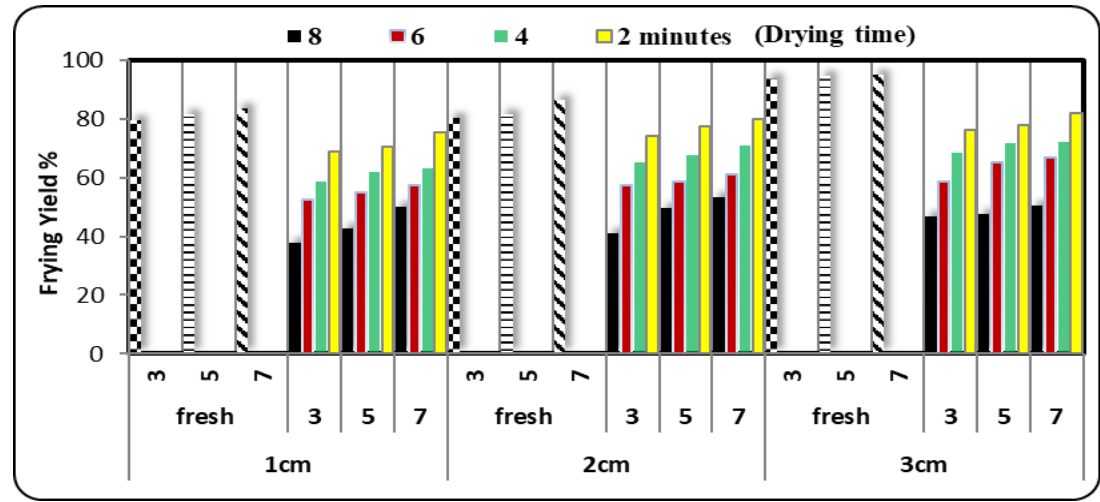

(a) Microwave power 320 Watt

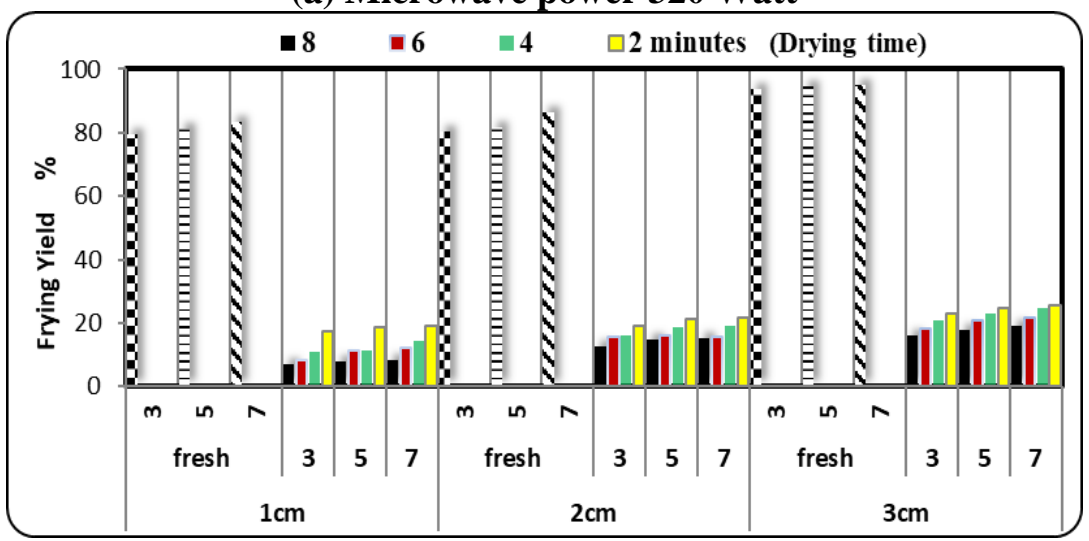

(b) Microwave power 540 Watt

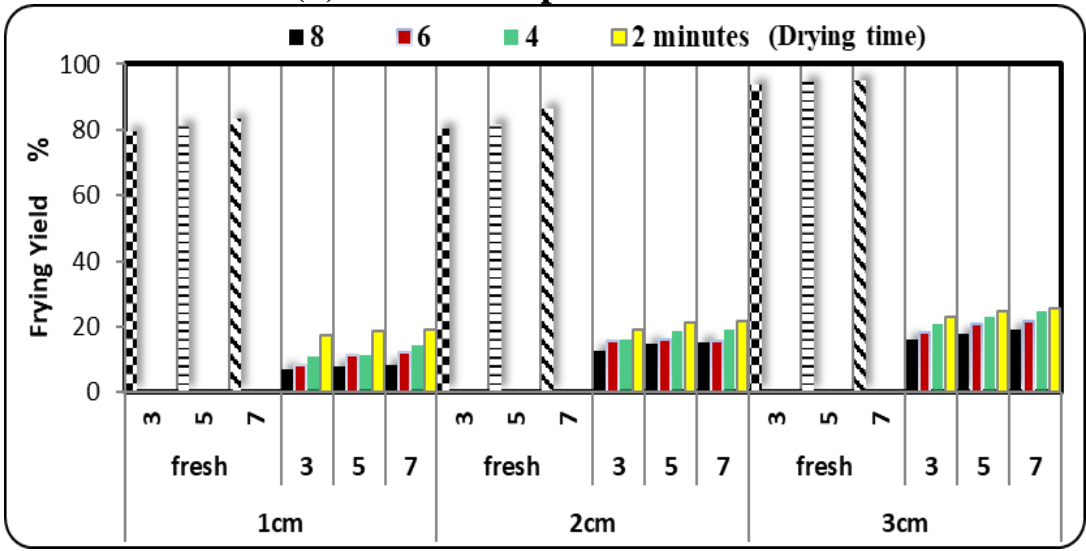

(c) Microwave power 720 Watt

Figure $1(a, b$, and c): Frying yield of eggplant slices as results of different treatments. 


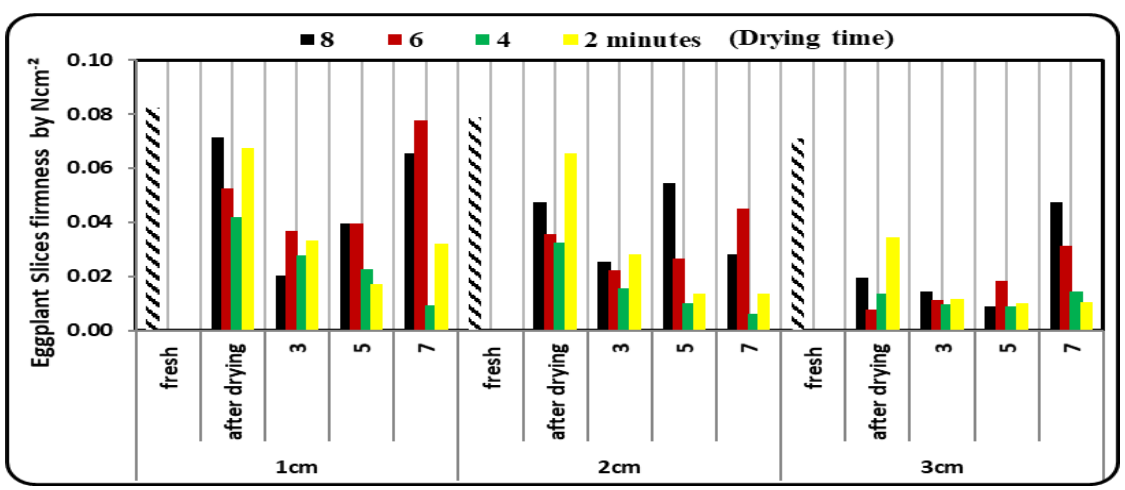

(a) Microwave power 320 Watt

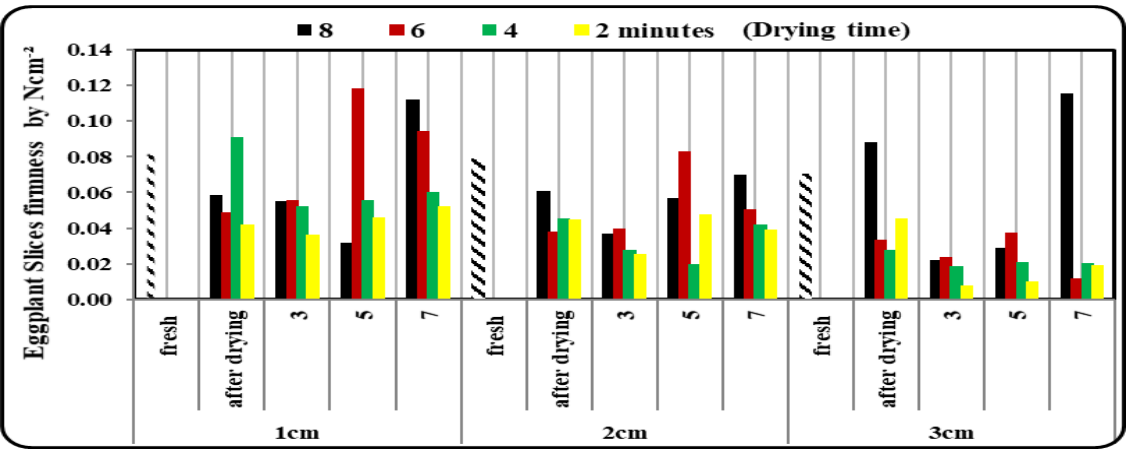

(b) Microwave power 540 Watt

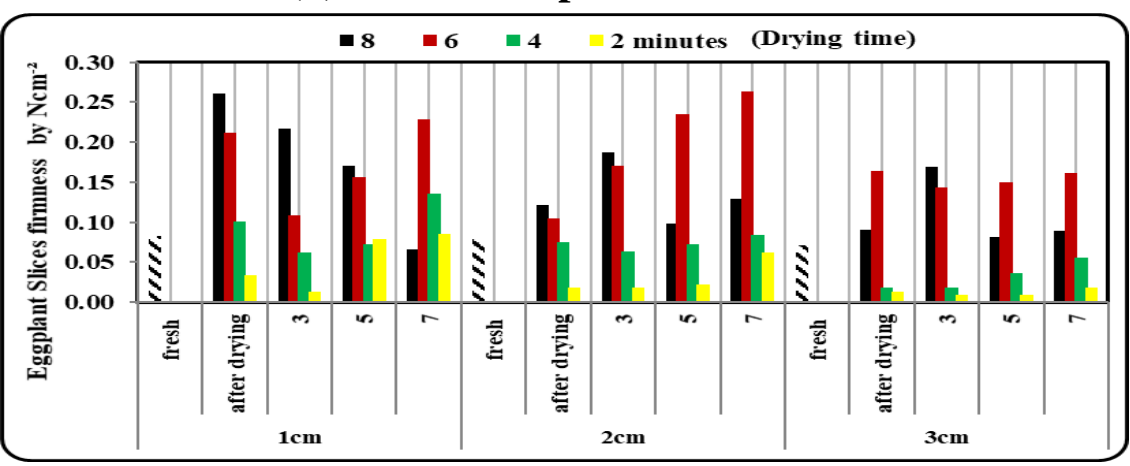

(c) Microwave power 720 Watt

Figure 2 (a, b, and c): Eggplant slices firmness as a result of different treatments

These figures and means statistically significant data analysis for effect of different treatments on $\Delta \mathrm{E}$ that frying time result in highly significant effect (at $0.01 \%$ ) on $\Delta \mathrm{E}$ but, the microwave powers and eggplant slices thicknesses result in significant effect (at $0.05 \%$ ) while, the drying time result in non-significant effect. 


\subsection{Browning index $(\mathrm{Bi})$}

Browning reaction is the main reason for the color changes in food during thermal processing. Browning index is the purity of brown color and can be calculate from all the interaction of L-values, a- values and b- values, Uthumporn, (2016).

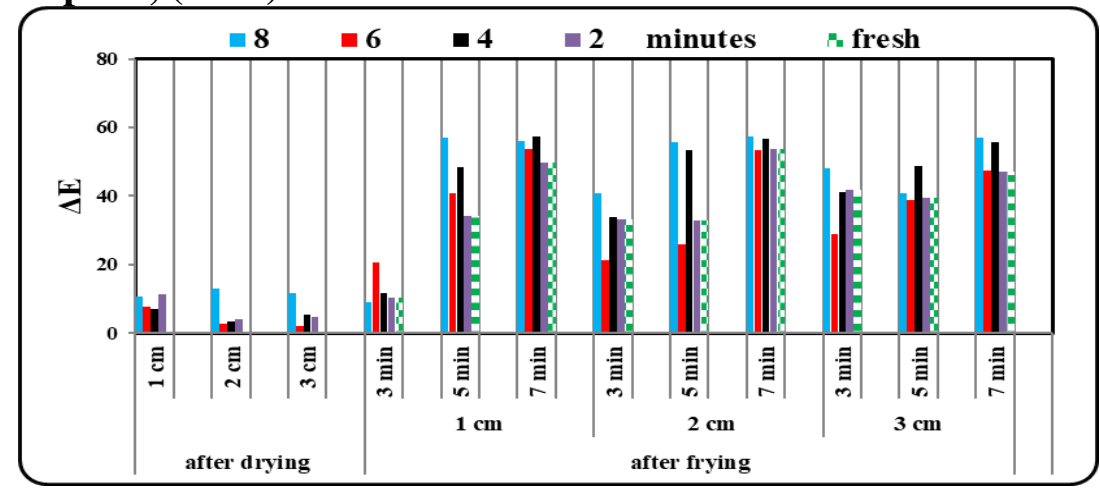

(a) Microwave power 320 Watt

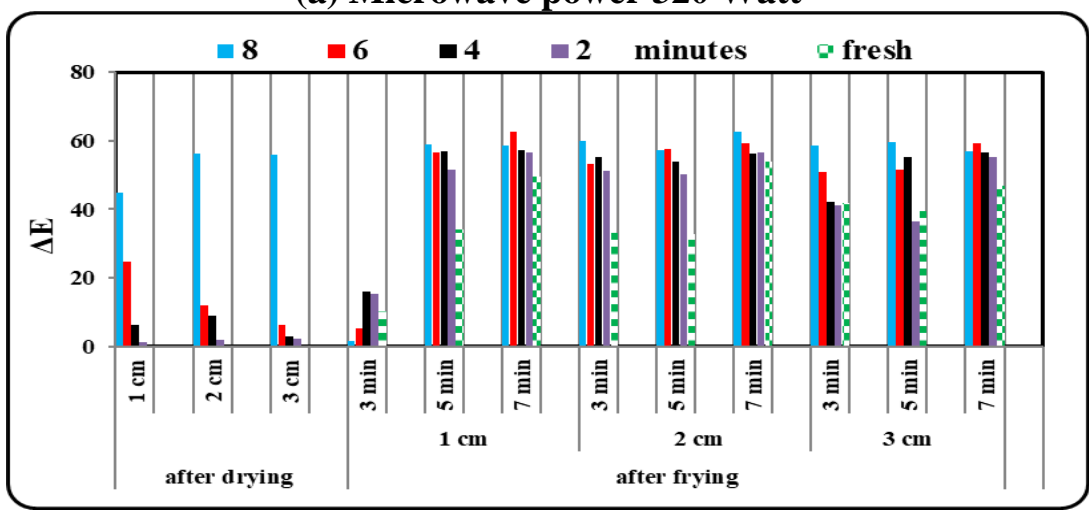

(b) Microwave power 540 Watt

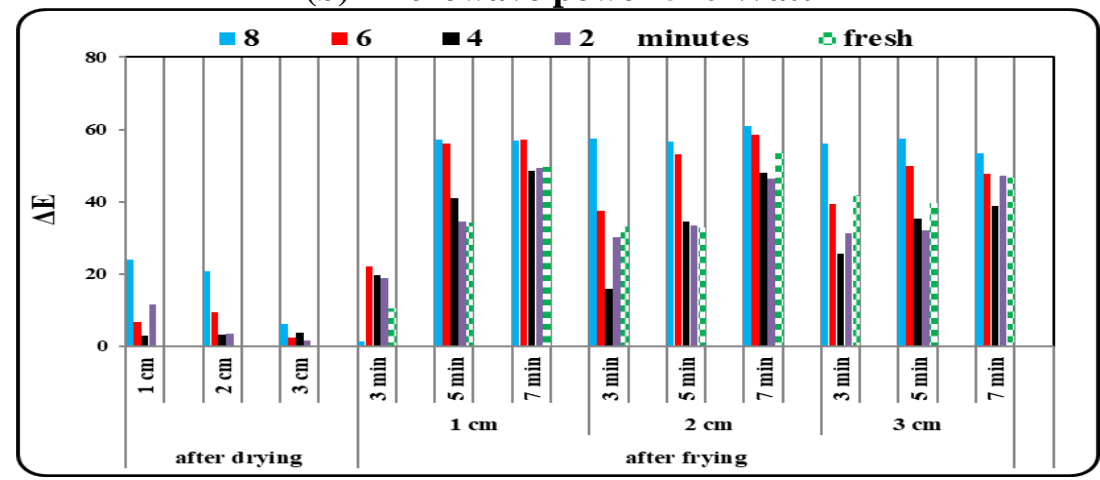

(c) Microwave power 720 Watt

Figure 3 (a, b, and c): Eggplant slices total difference of the color parameters $\Delta E$ as a result of different treatments 
Refer to the results in figure $4(\mathrm{a}, \mathrm{b}$, and $\mathrm{c})$ and means statistically significantly data analysis, there were highly significant effect of the drying time on the browning index.

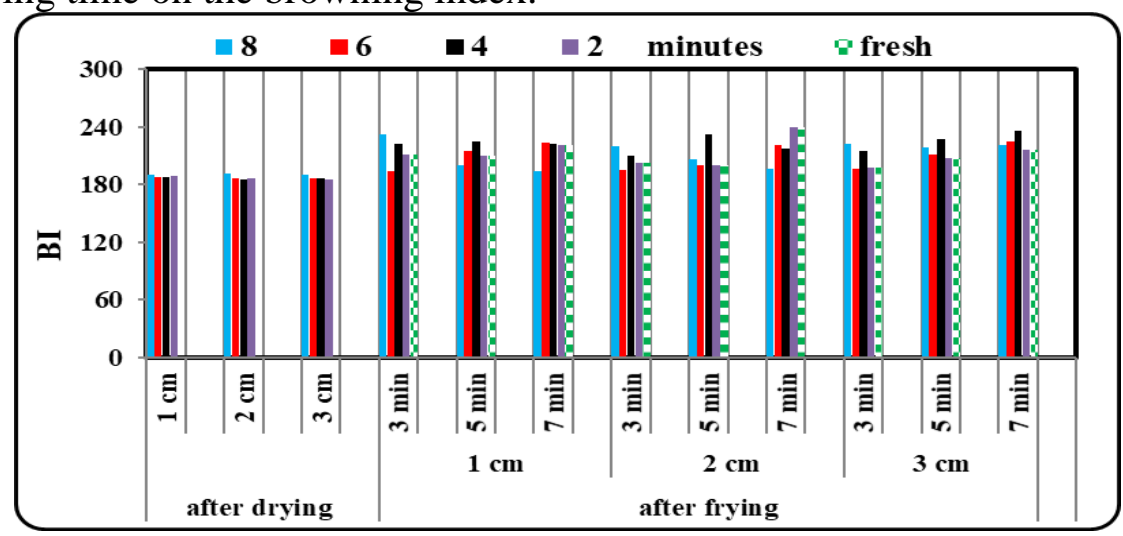

(a) Microwave power 320 Watt

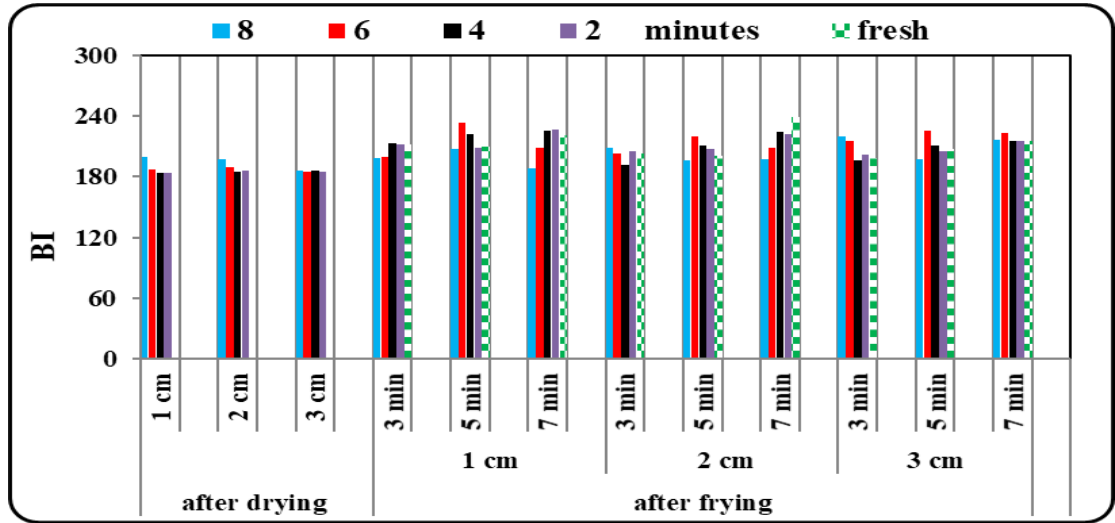

(b) Microwave power 540 Watt

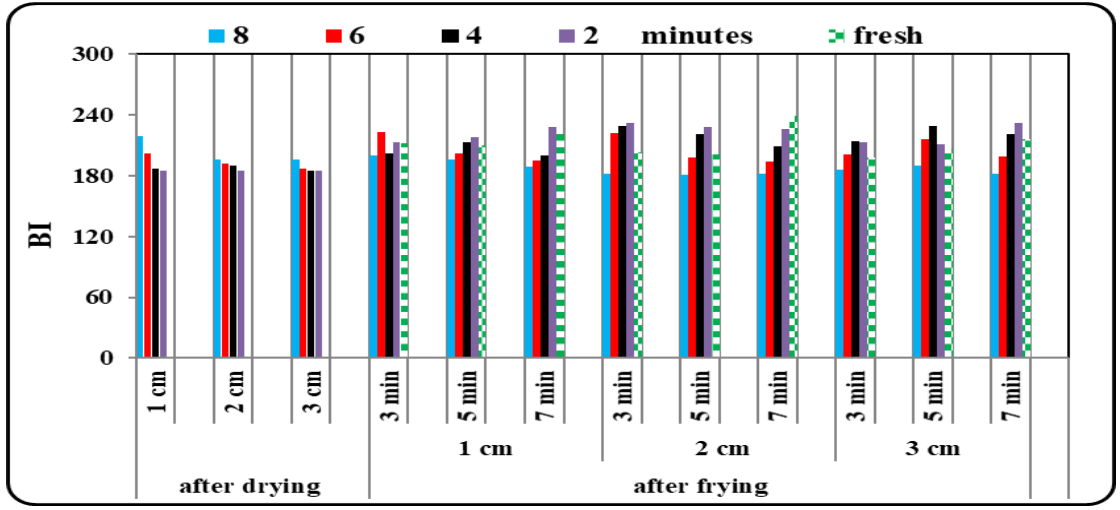

(c) Microwave power 720 Watt

Figure 4 (a, b, and c): Browning index of eggplant slices as a result of different treatments 
However, there were non-significant effect of microwave powers, eggplant slices thicknesses, and frying time on the browning index. The results show that, the dried eggplant slice with thickness $1 \mathrm{~cm}$ in microwave with power 540 Watt for 8 minutes was the lowest value of the browning index with 193.42.

\section{CONCLUSION}

Drying the eggplant slices with $1 \mathrm{~cm}$ thickness using 540 Watt of the microwave power for time of 8 minutes before frying it in oil at $180{ }^{\circ} \mathrm{C}$ for 7 minutes result in a good fried eggplant slice in textural and color with lowest oil uptake which favorite by consumers.

\section{REFERENCES}

Akanitapichat, P., K. Phraibung; K. Nuchklang and S. Prompitakkul, (2010). Antioxidant and hepatoprotective activities of five eggplant varieties. Food and Chemical Toxicology, 48:3017-3021.

AKDENIZ, N. (2004). Effects of different batter formulation on quality of deep-fat fried carrot. A thesis submitted to the graduate school of natural and applied sciences of Middle East technical university.

Arabhosseini, A., S. Padhye, W. Huisman, A. van Boxtel and J. Müller. (2009). Effect of drying on the color of tarragon (Artemisia dracunculus L.) leaves. Food and Bioprocess Technology. Doi: 10.1007/s11947-009-0305-9.

Available:

http://iftconfex.com/ift/2001/techprogram/paper_7480.htm.

Baixauli, S.A., S. M. Fiszman, and C. Calvo. (2002). Effect of addition of Corn flour and colorants on the color of fried, battered squid rings European Food Research and Technology 215: 457- 461.

Berk Zeki, (2009). Food Process Engineering and Technology, Chapter 3:

Heat and Mass Transfer, Basic Principles. Pages 69-113. https://doi.org/10.1016/B978-0-12-373660-4.00003-X.

Blumenthal, M.M. (1991). A new look at the chemistry and physics of deep-fat frying. Food Technology, 45(2): 68-71, 94.

Cao, G., E. Sofic, and R. Prior, (1996). Antioxidant Capacity of Tea and Common Vegetables. Journal of Agriculture and Food Chemistry, 44: 3426-3431. 
Choe E. and, D.B. MIN. (2007). Chemistry of Deep-Fat Frying Oils, Journal of Food Science, Vol. 72, Nr. 5.

Debnath, S., K.K. Bhat., and N.K. Rastogi. (2003), Effect of pre-drying on kinetics of moisture loss and oil uptake during deep fat frying of chickpea flour-based snack food. Lebensm.-Wiss. U.- Technol. 36:91-98.

Eissa H. A., M. T. Ramadan, H. S. Ali and G. H. Ragab. (2013). Optimizing Oil Reduction in Fried Eggplant Rings. Journal of Applied Sciences Research, 9(6): 3708-3717.

FAOSTAT (2015). Production/Crops for Eggplant in 2013. Food and Agriculture Organization of the United Nations, Statistics Division.

Garcia, M.A C., Ferrero., N. Bertola., M. Martino., and N. Zaritsky. (2002). Effectiveness of edible coatings from cellulose derivatives to reduce fat absorption in deep fat frying. Innovative Food Science and Emerging Technologies 3:391-397.

Giese, J. (1996). Fats, oils, and fat replacers. Food Technology,50(4):7884.http://link.springer.de/link/serv...paper/s00217-002-0605zch100.html.

Kortei, N. K., Odamtten, G. T., Obodai, M., Appiah, V., Akonor, P. T. (2015). Determination of color parameters of gamma irradiated fresh and dried mushrooms during storage Croatian. Journal of Food Technology, Biotechnology and Nutrition 10 (1-2), 66-71.

Mellema, M. (2003). Mechanism and reduction of fat uptake in deep-fat fried foods. Trends in Food Science and Technology. 14, 364-373.

Moyano, P.C., V.K. Rioseco., P.A. Gonzalez. (2002). Kinetics ok crust color changes during deep-fat frying of impregnated French fries. Journal of Food Engineering, 54, 249-255.

Parinyasiri, T., T.C. Chen., and R.J. Reed. (1991). Yields and breading dispersion of chicken nuggets during deep-fat frying as affected by protein content of breading flour. Journal of Food Processing and Preservation. 15:369-376.

Salvador., Saenz. A., Fiszman, T., S. (2002). Effect of corn flour, salt, and leavening on the texture of fried, battered squid rings. Journal of Food Science. Vol.67, Nr.2: 730-733. 
Southern, C.R., X.D. Chen., M.M. Farid., B. Howard., and, L. Eyres. (2000). Determining internal oil uptake and water content of fried thin potato crisps. Food and Byproducts Processing. 78:119-125.

Stevenso, S. G., M. Vaisey- Genser., N. A. M Eskin. (1984). Quality control in the use of deep frying oils Journal American Oil Chemists' Society, 61: 1102-1108

Stier, R. F. (2000). Chemistry of frying and optimization of deep-fat fried food flavour - An introductory review. European Journal of Lipid Science Technology, 102: 507-514.

Uthumporn, U., D.L, Laila., M.S, Rabeta., H, Aida., A.S, Ruri. (2016). Effects of Different Cooking Methods on the Physico-Chemical and Quality Attributes of Eggplants. International journal on advanced science engineering information technology.Vol.6 No. 4: 460-464.

الملخص العربي - (المي

\section{بعض خواص الباذنجان المقلي المتأثرة بالتجفيف المبائي في فرن الميكروويف}

د/ عبد اللطيف عبد الوهاب سمك (')، د/ محمود حسن كشك (')، د/ محمد نبيه عمر (')

يعتبر الباذنجان المقلى من الأطعمة الدفضلة للإنسان لكن اثناء عملية القلي يحدث تغير فى اللون

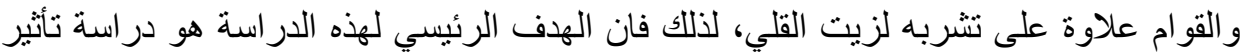

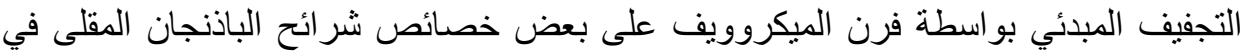

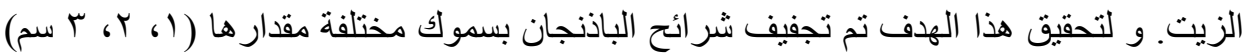

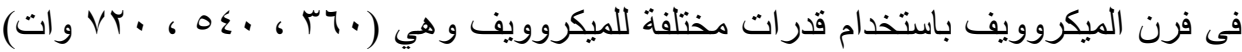

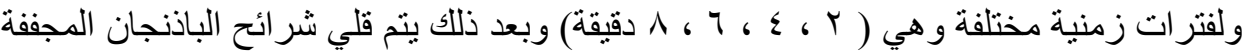

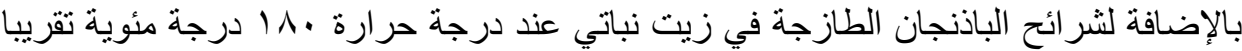

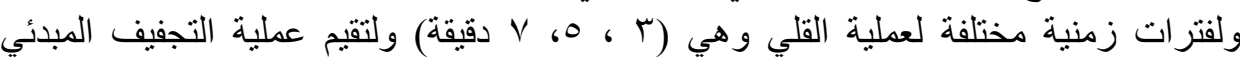

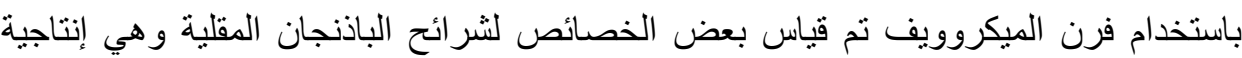

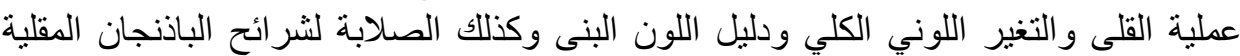
وكانت اهم النتائج المتحصل عليه اللوني كالاتي:-

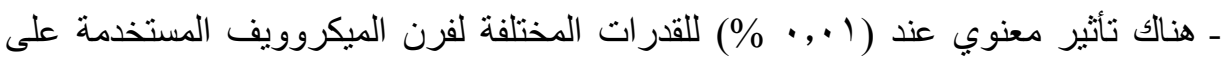

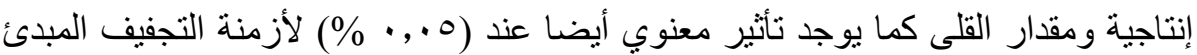

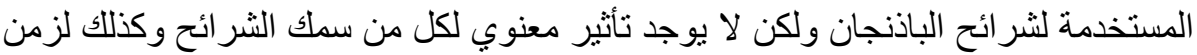

$$
\text { قلي شر ائح الباذنجان في الزيت. }
$$

(') مدرس بقسم الهندسة الزراعية ـ كلية الزراعة بشبين الكوم - جامعة المنوفية 


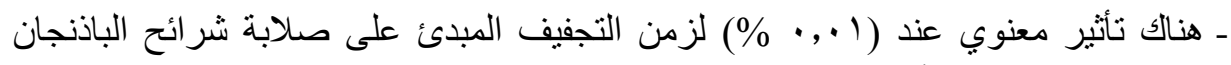
المقلية بينما لا يوجد تأثير معنوي لباقي عوامل المن الدراسة.

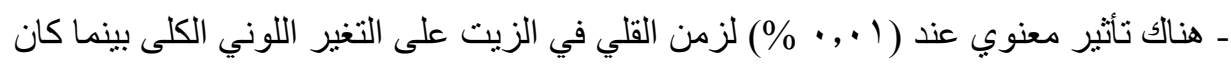

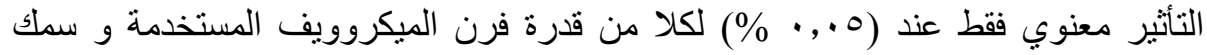

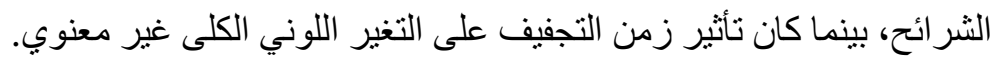

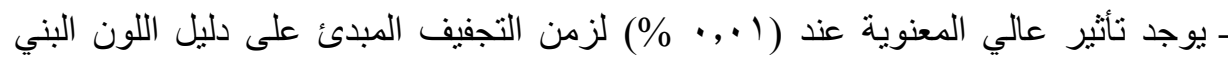

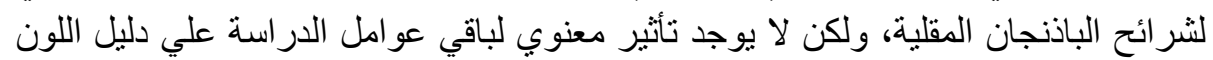
البني لنشر ائح الباذنجان المقلية.

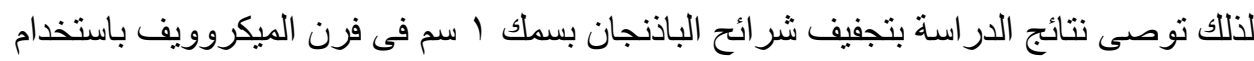

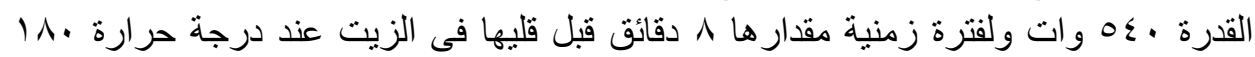

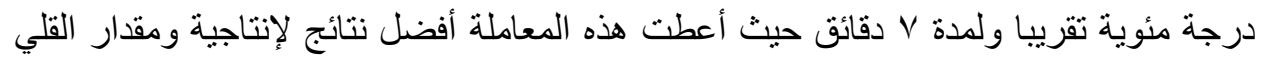
وكذللك الصلابة و التغير اللوني الكلي ودليل التلون البنى لثنر ائح الباذنجان المقلية. 